\section{Established and Seeded Buffalograss Tolerance to Herbicides Applied Preemergence}

\author{
Peter A. Dotray and Cynthia B. McKenney \\ Department of Plant and Soil Science, Texas Tech University, Lubbock, \\ TX 79409-2122
}

\section{Additional index words. herbicide types, turfgrass management}

\begin{abstract}
Experiments were conducted to evaluate established and seeded buffalograss [Buchloe dactyloides (Nutt.) Engelm.] tolerance to herbicides applied preemergence at labeled use rates. Established buffalograss tolerated benefin, benefin plus oryzalin, benefin plus trifluralin, DCPA, dithiopyr, isoxaben, oryzalin, pendimethalin, and prodiamine. For established buffalograss treated with atrazine, diuron, or metolachlor, the injury rating was $27 \%$ to $71 \%$ at 6 weeks after treatment (WAT) and $22 \%$ to $84 \%$ at 15 WAT. Buffalograss tolerated cyanazine, metsulfuron, propazine, and pyrithiobac applied in the seedbed. Seeded buffalograss stands were reduced by alachlor, atrazine, dicamba, linuron, metolachlor, metribuzin, oryzalin, pendimethalin, and quinclorac. Stand reductions by dicamba (a preplant and postemergence herbicide), up to $100 \%$ at 4 WAT and up to $85 \%$ at 16 WAT, were those most severe. Seeded and established buffalograss showed excellent tolerance to a few preemergence herbicides that could be used effectively and safely to control weeds during establishment and maintenance of buffalograss. Chemical names used: 2-chloro- $N$-(2,6-diethylphenyl)- $N$-(methoxymethyl) acetamide (alachlor); 6-chloro- $N$-ethyl- $N^{\prime}$-(1-methylethyl)-1,3,5-triazine-2,4-diamine (atrazine); $N$-butyl- $N$-ethyl-2,6-dinitro-4-(trifluoromethyl)benzenamine (benefin); 2-[[4-chloro6-(ethylamino)-1,3,5-triazin-2-yl]amino]-2-methylpropanenitrile (cyanazine); dimethyl 2,3,5,6-tetrachloro-1,4-benzenedicarboxylate (DCPA); 3,6-dichloro-2-methoxybenzoic acid (dicamba); $S, S$-dimethyl 2-(difluoromethyl)-4-(2-methylpropyl)-6-(trifluoromethyl)-3,5pyridinedicarbothioate (dithiopyr); $N^{\prime}$-(3,4-dichlorophenyl)- $N, N$-dimethylurea (diuron); $N$-[3-(1-ethyl-1-methylpropyl)-5-isoxazolyl]-2,6-dimethoxybenzamide (isoxaben); $N^{\prime}$-(3,4dichlorophenyl)- $N$-methoxy- $N$-methylurea (linuron); 2-chloro- $N$-(2-ethyl-6methylphenyl)- $N$-(2-methoxy-1-methylethyl)acetamide (metolachlor); 4-amino-6-(1,1dimethylethyl)-3-(methylthio)-1,2,4-triazin-5(4H)-one (metribuzin); 2-[[[[(4-methoxy-6methyl-1,3,5-triazin-2-yl)amino]carbonyl]amino]sulfonyl]benzoic acid (metsulfuron); 4(dipropylamino)-3,5-dinitrobenzenesulfonamide (oryzalin); $N$-(1-ethylpropyl)-3,4dimethyl-2,6-dinitrobenzenamine (pendimethalin); $N^{3}, N^{3}$-di- $n$-propyl-2,4-dinitro-6(trifluoromethyl)-m-phenylenediamine (prodiamine); 6-chloro- $N, N^{\prime}$-bis(1-methylethyl)1,3,5-triazine-2,4-diamine (propazine); 2-chloro-6-[(4,6-dimethoxy-2-pyrimidinyl) thio]benzoic acid (pyrithiobac); 3,7-dichloro-8-quinolinecarboxylic acid (quinclorac); Team $^{\mathrm{TM}}$ [premix of $1.33 \%$ benefin and $0.67 \%$ 2,6-dinitro- $N, N$-dipropyl-4(trifluoromethyl)benzenamine] (trifluralin).
\end{abstract}

Buffalograss is a stoloniferous, warmseason turfgrass native throughout the shortand mixed-grass prairies of the North American Great Plains (Correll and Johnston, 1979). Buffalograss has greater drought and hightemperature and low-temperature tolerance than common bermudagrass [Cynodon dactylon (L.) Pers.], zoysiagrass (Zoysia japonica Steud.), tall fescue (Festuca

Received for publication 7 Aug. 1995. Accepted for publication 18 Feb. 1996. Contribution of the Dept. of Plant and Soil Science, College of Agricultural Sciences and Natural Resources, Texas Tech Univ. publication no. T-4-400. Mention of a trademark, vendor, or proprietary product does not constitute a guarantee or warranty of the product by Texas Tech Univ. and does not imply its approval to the exclusion of other products or vendors that may also be suitable. The cost of publishing this paper was defrayed in part by the payment of page charges. Under postal regulations, this paper therefore must be hereby marked advertisement solely to indicate this fact.

HortSCience, Vol. 31(3), June 1996
Prairie. [(3,5,6-Trichloro-2-pyridinyl)oxy] acetic acid (triclopyr) at $0.56 \mathrm{~kg} \cdot \mathrm{ha}^{-1},(2,4-$ dichlorophenoxy)acetic acid (2,4-D) at 1.12 $\mathrm{kg} \cdot \mathrm{ha}^{-1}, 2-[[[[(4,6$-dimethyl-2-pyrimidinyl) amino]carbonyl]amino]-sulfonyl]benzoic acid (sulfometuron) at $0.017 \mathrm{~kg} \cdot \mathrm{ha}^{-1}$, dicamba at $0.56 \mathrm{~kg} \cdot \mathrm{ha}^{-1}$, and a three-way mixture of 2,4-D +2 [(4-chloro-o-tolyl)oxy]propionic acid (mecoprop) + dicamba $(1.2+0.13+0.54$ $\mathrm{kg} \cdot \mathrm{ha}^{-1}$ ) caused marginally acceptable buffalograss quality 20 to 30 days after treatment. 'Prairie' buffalograss needed 20 days to recover from atrazine at $2.24 \mathrm{~kg} \cdot \mathrm{ha}^{-1}$, but ' $\mathrm{Oa}$ sis' buffalograss did not recover from 2,4-D or 2,4-D + dicamba + mecoprop applications. 3[2,4-Dichloro-5-(1-methylethoxy)phenyl]-5(1,1-dimethylethyl)-1,3,4-oxadiazol-2-(3H)one (oxadiazon) and isoxaben plus trifluralin did not cause visible injury to buffalograss plugs, but isoxaben alone affected lateral growth and establishment (Harivandi and Elmore, 1993). Dithiopyr at $0.6 \mathrm{~kg} \cdot \mathrm{ha}^{-1}$, quinclorac at $0.8 \mathrm{~kg} \cdot \mathrm{ha}^{-1}$, monosodium methanearsonate (MSMA) at $2.2 \mathrm{~kg} \cdot \mathrm{ha}^{-1}$, and 3,6-dichloro-2-pyridinecarboxylic acid (clopyralid) at $0.8 \mathrm{~kg} \cdot \mathrm{ha}^{-1}$ did not injure 'Sharp's Improved' buffalograss seedlings that had one to three leaves in 1 year and two to four tillers in another (Fry and Upham, 1994).

Most preemergence herbicides can be applied only to established turfgrass (Murphy, 1994). Few studies have been conducted to determine buffalograss establishment from seed and its tolerance to herbicides applied preemergence. Buffalograss seed germination was not affected by clopyralid at rates up to 9.0 $\mathrm{kg} \cdot \mathrm{ha}^{-1}$, but was suppressed by 4 -amino-3,5,6trichloro-2-pyridinecarboxylic acid (picloram) and trichlopyr at $1.1 \mathrm{~kg} \cdot \mathrm{ha}^{-1}$ and 2,4,5-T at 9.0 $\mathrm{kg} \cdot \mathrm{ha}^{-1}$ (Huffman and Jacoby, 1984). Fermanian et al. (1980) determined that seeded bermudagrass was moderately tolerant to 4amino-6-tert-butyl-3-(methylthio)-as-triazin$5(4 H)$-one (metribuzin) at $0.42 \mathrm{~kg} \cdot \mathrm{ha}^{-1}$ and $2-$ (tert-butylamino)-4-(ethylamino)-6(methylthio)-s-triazine (terbutryn) at 1.36 $\mathrm{kg} \cdot \mathrm{ha}^{-1}$, but highly sensitive to 2-tert-butyl4(2,4-dichloro-5-isopropoxyphenyl)- $\Delta^{2}-1,3,4$ oxadiazolin-5-one (oxadiazon) at 0.79 $\mathrm{kg} \cdot \mathrm{ha}^{-1}$ and 1-(2-methylcyclohexyl)-3phenylurea (siduron) at $0.23 \mathrm{~kg} \cdot \mathrm{ha}^{-1}$. Bovey and Voigt (1983) reported that of 23 herbicides applied in the seedbed, 'Morpa' and 'Renner' weeping lovegrass [Eragrostis curvula (Schrad.) Nees] were tolerant to propazine and $S$-ethyl bis(2-methylpropyl) carbamothioate (butylate) at $2.2 \mathrm{~kg} \mathrm{ha}^{-1}$. 'Renner' was tolerant to atrazine, diuron, and 2 - chloro- $N-(1-$ meth y leth y 1$)-N$ phenylacetamide (propachlor) applied in the seedbed at $0.6 \mathrm{~kg} \cdot \mathrm{ha}^{-1}$. In cool-season grasses, Fermanian and Haley (1994) reported that prodiamine applied to juvenile ( $<1$ year old) Kentucky bluegrass at $1.4 \mathrm{~kg} \cdot \mathrm{ha}^{-1}$ caused a significant loss of quality. In 3 years of research, fall applications of prodiamine at 0.8 and $2.2 \mathrm{~kg} \cdot \mathrm{ha}^{-1}$ and DCPA at $23.5 \mathrm{~kg} \cdot \mathrm{ha}^{-1}$ significantly reduced overseeded Kentucky bluegrass populations 2 years after planting.

The objective of this research was to determine established and seeded buffalograss tolerance to herbicides applied preemergence. 


\section{Materials and Methods}

Established buffalograss tolerance. Field experiments were conducted in 1994 near Bronco (1155 m altitude), Texas [Portales fine sandy loam (fine-loamy, mixed, thermic Aridic Calciustoll)], and at the Texas Tech Univ. greenhouse facility in Lubbock $(960 \mathrm{~m}$ altitude) [Amarillo fine sandy loam (fine-loamy, mixed, thermic Aridic Paueustalf)]. All experimental sites had $<1.4 \%$ organic matter in the topsoil and a pH of 8.1 to 8.4. Buffalograss ('Comanche') caryopses were broadcast by hand at $27 \mathrm{~kg} \cdot \mathrm{ha}^{-1}$ in May 1992 at Bronco under a center-pivot sprinkler irrigation system. Buffalograss was maintained with supplemental water and fertilized according to soil test recommendations (A\&L Agricultural Laboratories, Lubbock, Texas) for grass seed production. In 1994, on-site rainfall in Bronco was $280 \mathrm{~mm}$ and supplemental irrigation was $500 \mathrm{~mm}$. Individual $2.0 \times 7.3-\mathrm{m}$ plots under the center-pivot sprinkler irrigation system were developed in this established buffalograss area.

AtLubbock, buffalograss ('Comanche' and 'Texoka') caryopses were planted in May 1992 in $2 \times 2-\mathrm{m}$ plots as described above. Aboveground sprinklers with micro-spinner emitters provided supplemental irrigation. The buffalograss was maintained with supplemental water $(500 \mathrm{~mm})$ and fertilized midseason with sulfur-coated urea ( $\left.39 \mathrm{~kg} \cdot \mathrm{ha}^{-1}\right)$ according to soil test recommendations.

Herbicides (see Table 1) were applied to established dormant buffalograss in March at both experimental sites. Applications were made using a $\mathrm{CO}_{2}$-pressurized backpack sprayer that delivered a carrier volume of 140 liters.ha ${ }^{-1}$. Teejet (Spraying Systems Co., Wheaton, Ill.) 8002 nozzle tips were used at $207 \mathrm{kPa}$ pressure.

Buffalograss injury was rated visually 6 and 15 weeks after treatment (WAT) using a $0 \%$ to $100 \%$ scale and comparing herbicidetreated turf to nontreated turf for greenup, density, living ground cover, and quality. All plots were hand-weeded to minimize weed competition. At the end of the growing season, when the buffalograss was no longer green, a $10-\mathrm{cm}$-diameter area was randomly selected and hand-clipped at the soil surface in each plot. The resulting above-ground biomass was oven-dried at $60 \mathrm{C}$ for $72 \mathrm{~h}$ and weighed. Dry weight values are presented as a percentage of the nontreated control.

The design was a randomized complete block with four replications at Bronco and a randomized complete block, split-plot design with five replications at Lubbock. At Lubbock, main plots were cultivars and subplots were herbicide treatments. All data were subjected to analysis of variance (ANOVA). Means were separated using Fisher's Protected LSD test at $P \leq 0.05$ (Steel and Torrie, 1980).

Seeded buffalograss tolerance. Field experiments were conducted in 1993 and 1994 at the Texas Tech Univ. Erskine Research facility in Lubbock. The Amarillo fine sandy loam (fine-loamy, mixed, thermic Aridic Paueustalf) had a $\mathrm{pH}$ of 7.6 and $1.3 \%$ organic matter.
Buffalograss ('Comanche') caryopses were broadcast by hand at $27 \mathrm{~kg} \cdot \mathrm{ha}^{-1}$ in individual $2.0 \times 7.3-\mathrm{m}$ plots. Soil was moist at germination and supplemented with $1000 \mathrm{~mm}$ irrigation during the study using above-ground sprinklers with micro-spinner emitters.

Herbicides (see Table 2) were soil-applied within $24 \mathrm{~h}$ after seeding, as described above, and followed by $\approx 25 \mathrm{~mm}$ of irrigation. Buffalograss stand density was evaluated 4 WAT and 10 to 16 WAT. A visual estimation of turf density, based on a scale of $0 \%$ (bare ground) to $100 \%$ (complete coverage), was recorded at each observation date. All plots were hand-weeded to minimize weed competition. Above-ground biomass was harvested at the end of the growing season as described previously.

The design was a randomized complete block with four replications. All data were subjected to ANOVA. Means were separated using Fisher's protected LSD test at $P \leq 0.05$ (Steel and Torrie, 1980).

\section{Results and Discussion}

Established buffalograss tolerance. At Lubbock, cultivar $\times$ treatment interactions were nonsignificant; therefore, cultivars were combined within treatments. Treatment $\times$ location interactions also were nonsignificant; thus, data from Bronco and Lubbock were combined.

Established buffalograss treated with atrazine, diuron, or metolachlor was rated $\geq 27 \%$ for injury 6 WAT (Table 1). Buffalograss injury was greatest with atrazine and diuron. None of the other herbicides or herbicide combinations caused serious buffalograss injury.

At 15 WAT, buffalograss treated with atrazine, diuron, or metolachlor was rated $\geq 22 \%$ for injury (Table 1). Buffalograss injury was greatest with diuron, followed by atrazine and metolachlor. Buffalograss injury by 6-chloro$N, N^{\prime}$-diethyl-1,3,5-triazine-2,4-diamine (simazine) increased from $7 \%$ at 6 WAT to $11 \%$ at 15 WAT. No other herbicides caused objectionable buffalograss injury.

Table 1. Established buffalograss injury following preemergence herbicide treatments, 1994; data for Bronco and Lubbock, Texas, combined.

\begin{tabular}{|c|c|c|c|c|}
\hline \multicolumn{2}{|c|}{ Herbicide } & Buffal & $y^{2}(\%)$ & Biomass $^{y}(\%)$ \\
\hline & Rate & \multicolumn{3}{|c|}{ Weeks after treatment } \\
\hline Compound(s) & $\left(\mathrm{kg} \cdot \mathrm{ha}^{-1}\right)$ & 6 & 15 & 30 \\
\hline Atrazine & 2.2 & 71 & 62 & 48 \\
\hline Benefin & 3.4 & 4 & 2 & 110 \\
\hline Benefin + oryzalin & $1.7+1.7$ & 1 & 0 & 105 \\
\hline Benefin + trifluralin & $2.3+1.1$ & 2 & 1 & 106 \\
\hline DCPA & 16.8 & 1 & 0 & 125 \\
\hline Dithiopyr & 0.6 & 1 & 2 & 96 \\
\hline Diuron & 2.8 & 67 & 84 & 41 \\
\hline Isoxaben & 1.1 & 1 & 0 & 109 \\
\hline Metolachlor & 4.5 & 27 & 22 & 81 \\
\hline Oryzalin & 2.2 & 1 & 0 & 109 \\
\hline Pendimethalin & 3.4 & 1 & 0 & 108 \\
\hline Prodiamine & 1.7 & 1 & 0 & 107 \\
\hline Simazine & 2.2 & 7 & 11 & 83 \\
\hline Nontreated & --- & 0 & 0 & 100 \\
\hline $\operatorname{LSD}_{(0.05)}$ & --- & 10 & 4 & 15 \\
\hline
\end{tabular}

${ }^{2}$ Buffalograss injury using a $0 \%$ to $100 \%$ scale was based on greenup, density, living ground cover, and quality as compared to a nontreated control.

${ }^{y}$ Above-ground buffalograss tissue was harvested after it was no longer green and then was oven-dried. Biomass yield is expressed as a percentage of the nontreated control.

Table 2. Seeded buffalograss stand following preemergence herbicide treatments, Lubbock, Texas.

\begin{tabular}{|c|c|c|c|c|c|c|}
\hline & & & & sss sta & & Biomass $^{\mathrm{y}}(\%)$ \\
\hline & icide & & & & 1994 & \\
\hline & Rate & & & ks aft & ent & \\
\hline Compound & $\left(\mathrm{kg} \cdot \mathrm{ha}^{-1}\right)$ & 4 & 10 & 4 & 16 & 21 \\
\hline Alachlor & 3.4 & 22 & 25 & 49 & 85 & 78 \\
\hline Atrazine & 2.2 & 28 & 34 & 0 & 17 & 28 \\
\hline Cyanazine & 1.7 & 77 & 79 & 72 & 95 & 108 \\
\hline Dicamba & 0.3 & 9 & 5 & 0 & 15 & 14 \\
\hline Linuron & 1.1 & 9 & 17 & 44 & 25 & 0 \\
\hline Metolachlor & 3.4 & 11 & 15 & 4 & 25 & 37 \\
\hline Metribuzin & 1.1 & 9 & 16 & 0 & 36 & 22 \\
\hline Metsulfuron & 0.017 & 95 & 100 & 73 & 88 & 125 \\
\hline Oryzalin & 1.7 & 43 & 45 & 56 & 72 & 112 \\
\hline Pendimethalin & 1.7 & 44 & 48 & 2 & 19 & 44 \\
\hline Propazine & 1.7 & 76 & 81 & 83 & 99 & 114 \\
\hline Pyrithiobac & 0.07 & 78 & 84 & 72 & 96 & 105 \\
\hline Quinclorac & 0.6 & 22 & 29 & 19 & 32 & 19 \\
\hline Nontreated & --- & 100 & 100 & 100 & 100 & 100 \\
\hline $\operatorname{LSD}_{(0.05)}$ & --- & 28 & 26 & 29 & 29 & 45 \\
\hline
\end{tabular}

${ }^{\mathrm{z} B u f f a l o g r a s s}$ stand based on a scale of $0 \%$ (bare ground) to $100 \%$ (complete coverage) was rated visually as compared to a nontreated control.

${ }^{y}$ Above-ground buffalograss tissue was harvested after it was no longer green and then was oven-dried. Biomass yield is expressed as a percentage of the nontreated control. 
Buffalograss biomass reduction relative to the control ranged from $17 \%$ to $59 \%$ where atrazine, diuron, metolachlor, or simazine were applied (Table 1). Biomass reductions were greatest with atrazine and diuron followed by metolachlor and simazine. No other herbicide treatment induced a reduction in biomass.

Seedling buffalograss tolerance. Treatment $\times$ year interactions were significant and data from 1993 and 1994 are reported separately.

In 1993, cyanazine, metsulfuron, propazine, and pyrithiobac did not reduce seeded buffalograss stand compared to nontreated buffalograss at 4 and 10 WAT (Table 2). Buffalograss stand was reduced $56 \%$ by pendimethalin and $57 \%$ by oryzalin at 4 WAT. Similar stand reductions were observed at 10 WAT where these herbicides were applied. Alachlor, atrazine, and quinclorac reduced buffalograss stand $72 \%$ to $78 \%$ at 4 WAT and $66 \%$ to $75 \%$ at 10 WAT. Stand reductions were $89 \%$ to $91 \%$ at $4 \mathrm{WAT}$ and $83 \%$ to $95 \%$ at $10 \mathrm{WAT}$ with dicamba, linuron, metolachlor, and metribuzin.

In 1994, as in 1993, cyanazine, metsulfuron, propazine, and pyrithiobac did not reduce seeded buffalograss stand compared to nontreated buffalograss (Table 2). Buffalograss stand was reduced $44 \%$ to $81 \%$ with alachlor, linuron, oryzalin, and quinclorac at 4 WAT and $15 \%$ to $75 \%$ at 16 WAT. Stand reductions of $96 \%$ to $100 \%$ at $4 \mathrm{WAT}$ and $64 \%$ to $85 \%$ at 16 WAT with atrazine, dicamba, metolachlor, metribuzin, and pendimethalin were those most severe.

There was a significant loss in above-ground biomass for buffalograss harvested 21 WAT following several herbicide treatments in 1994 (Table 2). Biomass losses were $56 \%$ and $63 \%$ with pendimethalin and metolachlor, respectively. Atrazine, dicamba, metribuzin, and quinclorac reduced buffalograss biomass by $78 \%$ to $86 \%$. No buffalograss biomass was measured where linuron was applied.

There was some commonality among herbicides that caused buffalograss injury and among herbicides that caused no objectionable injury. In general, photosynthetic inhibi- tors (atrazine and diuron), a shoot inhibitor (metolachlor), and a growth regulator (dicamba) were more injurious than mitotic inhibitors (benefin, oryzalin, pendimethalin, and prodiamine) and amino acid biosynthesis inhibitors (metsulfuron and pyrithiobac). The photosynthetic inhibitors propazine and simazine were exceptions because buffalograss injury caused by these herbicides was less severe than injury caused by other photosynthetic inhibitors.

Weed control was not evaluated in these studies. Weed control by these herbicides has been well-documented in established turfgrass (Fermanian et al., 1980; Liskey, 1995; Menn and Hall, 1994; Menn et al., 1994; Smith et al., 1991), in turfgrass grown from vegetative plugs (Harivandi and Elmore, 1993), and in other horticultural and agronomic crops (Weed Science Society of America, 1994). All herbicides, except diuron (Table 1) and alachlor, cyanazine, linuron, propazine, pyrithiobac, and quinclorac (Table 2), are currently labeled for use in established turfgrass. However, these herbicides are not labeled for use in the seedbed because of the perceived turfgrass sensitivity to all herbicides at seedling emergence. Turfgrass tolerance to herbicides at seedling emergence would lead to a more rapid and uniform turfgrass stand.

At two locations on the Southern High Plains, where low soil organic matter and high-pH soils predominate, established buffalograss tolerated benefin, benefin plus oryzalin, benefin plus trifluralin, DCPA, dithiopyr, isoxaben, oryzalin, pendimethalin, and prodiamine. Atrazine, diuron, and metolachlor treatments caused significant injury and these herbicides should be avoided. Seeded buffalograss was sensitive to most of the herbicides applied preemergence, but tolerated cyanazine, metsulfuron, propazine, and pyrithiobac.

\section{Literature Cited}

Bovey, R.W. and P.W. Voigt. 1983. Tolerance of weeping lovegrass cultivars to herbicides. Crop Sci. 23:364-368.
Correll, D.S. and M.C. Johnston. 1979. Manual of the vascular plants of Texas. Univ. of Texas Printing Div., Austin.

Fermanian, T.W. and J.E. Haley. 1994. Application of prodiamine to immature turfs. Weed Technol. 8:617-620.

Fermanian, T.W., W.W.Huffine, and R.D. Morrison. 1980. Preemergence weed control in seeded bermudagrass stands. Agron. J. 72:803-805.

Fry, J.D. and W.S. Upham. 1994. Buffalograss seedling tolerance to postemergence herbicides. HortScience 29:1156-1157.

Fry, J.D., W.S. Upham, and L. Leuthold. 1993. Seeding month and seed soaking affect buffalograss establishment. HortScience 28:902 903.

Harivandi, M.A. and C.L. Elmore. 1993. Preemergence herbicide use during buffalograss establishment. Intl. Turfgrass Soc. Res. J. 7:298-302.

Huffman, A.H. and P.W. Jacoby, Jr. 1984. Effects of herbicides on germination and seedling development of three native grasses. J. Range Mgt. 37:40-43.

Liskey, E. (ed.). 1995. Turfgrass chemical update: Herbicides. Grounds Maintenance 30:57-67.

McCarty, L.B. and D.L. Colvin. 1992. Buffalograss tolerance to postemergence herbicides. HortScience 27:898-899.

Menn, W.G. and M.H. Hall. 1994. Evaluation of fall and spring applications of isoxaben (Gallery) for pre-emergent control of broadleaf weeds, $p$. 92-93. In: P.F. Colbaugh and S.P. Metz (eds.). Texas turfgrass research-1993. PR-5135.

Menn, W.G., M.H. Hall, and F.C. Teeter. 1994 Effectiveness of ASC67040 in controlling smooth crabgrass and slender aster in common bermudagrass, p. 94-95. In: P.F. Colbaugh and S.P. Metz (eds.). Texas turfgrass research1993. PR-5136.

Murphy, T.R. 1994. Post-emergence weed control in warm-season turfgrasses. Landscape Mgt. 33:42-46.

Smith, J., B. Bean, C. Patrick, R. Duble, W. Knoop, M. Hickey, W. Horne, L. Wilson, and R. Thomason. 1991. Turfgrass management for the Texas Panhandle. Texas Agr. Ext. Serv. B5014.

Steel, R.G.D. and J.H. Torrie. 1980. Principles and procedures of statistics. 2nd ed. McGraw-Hill Book Co., New York.

Weed Science Society of America. 1994. Herbicide handbook. 7th ed. Weed Sci. Soc. Amer., Champaign, Ill. 